mag. Gorazd

Vrabič,

dr. Tomaž

Klobučar

Inštitut Jožef

Stefan

\title{
Izmenjava učnega gradiva za potrebe e-izobraževanja
}

D od vsakega posameznika, da se nenehno izpopolnjuje, usposablja in dodatno izobražuje. Hiter razvoj komunikacijskih in informacijskih tehnologij, ki smo mu priča, to zahtevo še bolj postavlja v ospredje. Nove tehnologije omogočajo tudi razvoj sodobnih tehnologij za izobraževanje in prenos znanja na daljavo. V zadnjem času se jim posveča velika pozornost. In prav zato se morajo tudi izobraževalne in raziskovalne institucije prilagajati novim usmeritvam $\mathrm{v}$ Nastaja trg elektronskega učnega gradiva. izobraževanju $\mathrm{s}$ pripravo večpredstavnega učnega gradiva, ki ga ponujajo na daljavo po komunikacijskih omrežjih.

V svetu že nastajajo katalogi z najrazličnejšim izobraževalnim gradivom in izobraževalni portali, ki so omejeni predvsem na storitve svetovnega spleta. Pogosto so namenjeni le ozkemu krogu uporabnikov v okviru posameznih institucij in podjetij. Redko je izobraževalnega gradiva preveč in uporabnik zelo težko najde tisto, kar bi si želel. Premalo je tudi podpore v posameznih procesih izobraževanja na daljavo. Med ponudniki storitev in uporabniki ni koordinacije, uporabnikom pa so na voljo le seznami učnega gradiva, ne pa tudi dodatne storitve, na primer naročanje, obračunavanje, plačevanje, vrednotenje (evalvacija) in dostava gradiva.
V prispevku je predstavljen sistem za izme- njavo učnega gradiva med visokošolskimi institucijami $v$ Evropi in po svetu, ki odpravlja omenjene pomanjkljivosti na elektronskem izobraževalnem trgu. Sistem nastaja $\mathrm{v}$ zvezi $\mathrm{s}$ projektom UNIVERSAL (UNIVERSAL Exchange for PAN-European Higher Education), ki ga v okviru petega okvirnega programa sofinancira Evropska unija. Sistem deluje kot borza znanja, saj se na njej stikata dva osnovna elementa ekonomije, ponudba in povpraševanje, omogoča pa ponudbo učnega gradiva $\mathrm{v}$ različnih oblikah, iskanje po katalogih, naročanje in dejansko dostavo izobraževalnega gradiva končnim uporabnikom, na primer študentom.

\section{SISTEM UNIVERSAL MED PONUDNIKI IN UPORABNIKI}

Temeljni cilj projekta je uvesti sistem za posredovanje, ki temelji na standardnem principu opisovanja pedagoških, administrativnih in tehničnih lastnosti učnega gradiva. Sistem povezuje institucije, ki ponujajo učno gradivo in storitve s področja izobraževanja na daljavo, ter morebitne uporabnike teh storitev in tako omogoča lažji ter hitrejši pretok znanja. Ponudniki gradiva lahko izmenjujejo svoje znanje $\mathrm{z}$ drugimi ustanovami po svetu in pridobijo kakovostne povratne informacije za izboljšanje gradiva ter ustvarijo nove kanale za distribucijo. $\mathrm{Na}$ drugi strani omogoča sistem obogatitev la- 
Sistem temelji na najsodobnejsih tehnologijah in je združljiv $z$ nizom drugih izobraževalnih platform. Učečim se (na primer študentom) ponuja širšo izbiro uěnega gradiva, kot bi ga lahko uporabljali v izobraževanju v lastni izobraževalni ustanovi. Tako se poveča kakovost izobraževalnega procesa in končnega znanja. Hkrati omogoča tako imenovane$\mathrm{mu}$ navideznemu učitelju gibljivost $\mathrm{v}$ različno lociranih izobraževalnih institucijah. Posledica tega je uvajanje večje konkurence tudi med ponudniki znanja in $\mathrm{s}$ tem tudi izboljšanje kakovosti izo braževalnega procesa.

stnega izobraževalnega programa s kakovostnim dodatnim gradivom, ki ga ponujajo programi oddaljenih izobraževalnih institucij. Učitelji lahko dopolnijo predavanja s ponujenim gradivom, študenti pa dostopijo prek omrežja tudi do učnega gradiva drugih ustanov ali visokošolskih institucij in sodelujejo pri predavanjih ter razpravah v živo 0 . $\mathrm{Z}$ oblikovanjem izobraževalne platforme projekt opredeljuje tudi osnovne elemente, potrebne za podporo izobraževanju na daljavo in izmenjavo učnega gradiva. S tem postavlja temelje za razvoj novih tehnologij in aplikacij za ponudbo učnih gradiv na elektronskem trgu, enostavno in hitro iskanje, naročanje, dostavo in uporabo gradiva $\mathrm{z}$ zagotovljeno kakovostjo storitev.

\section{Vrednostna veriga sistema UNIVERSAL}

Vrednostna veriga, ki jo podpira sistem UNIVERSAL (slika 1), je sestavljena iz naslednjih stopenj: objava učnega gradiva, priprava ponudbe, oglaševanje, naročilo oziroma prijava in prenos učnega gradiva do uporabnika. Celoten proces pa spremlja evalvacija.

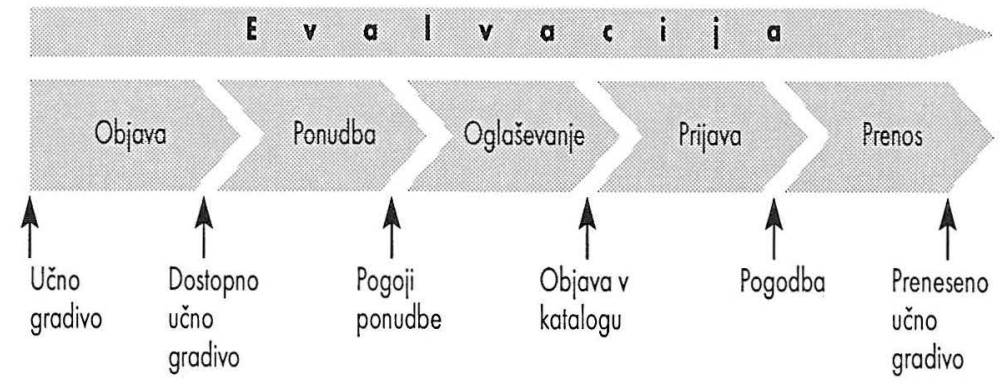

Slika 1: Vrednostna veriga sistema UNIVERSAL

\section{Objava}

Učno gradivo za izobraževanje na daljavo $\mathrm{v}$ grobem delimo na vnaprej pripravljeno gradivo in na predavanja $\mathrm{v}$ živo. V prvem primeru mora gradivo pred objavo $\mathrm{v}$ sistemu že obstajati. Shranjeno je lahko na strežniku ponudnika ali na osrednjem strežniku sistema UNIVERSAL. Pri predavanjih v živo mora avtor oziroma predavatelj jasno izraziti svoj namen pri izvajanju učnega procesa, ki mora biti časovno in vsebinsko natančno opredeljeno. Ponudniki pripravijo opis gradiva na podlagi metapodatkovne sheme. Metapodatkovna shema je predloga, s katero ponudniki objavijo naslov gradiva, opis in izobraževalne cilje, ime avtorja, pričakovani čas učenja, osnovne pogoje ipd. Opis, na podlagi katerega se uporabniki odločajo o izbiri, se v primerni obliki prikaže v katalogu 0 . Objavljeno učno gradivo ima lahko različne oblike (video posnetki, preprosta besedila, spletne strani, predstavitve, animacije, simulacije, vaje, aplikacije ipd.) in obseg. Evalvatorji lahko sistem oskrbijo $\mathrm{z}$ akreditacijskimi podatki o ponudnikih in njihovem učnem gradivu, ki povedo, koliko so ponudniki in njihovo gradivo priznani.

\section{Ponudba in oglaševanje}

Ponudnik učnega gradiva skladno s svojimi zahtevami oblikuje in objavi ponudbo, ki vsebuje pogoje uporabe gradiva. Učno gradivo je lahko na voljo brezplačno ali za denarno na- 
domestilo. V ponudbi so določeni pogoji za zaščito avtorskih pravic (prepoved kopiranja, nadaljnjega posredovanja ipd.), najmanjše ali največje število učečih se, ki hkrati uporabljajo gradivo, ipd. Ponudbi sledi oglaševanje učnega gradiva $\mathrm{v}$ katalogu in s tem je učno gradivo tudi dejansko objavljeno ter vidno $\mathrm{v}$ sistemu. Uporabniki lahko najdejo želeno učno

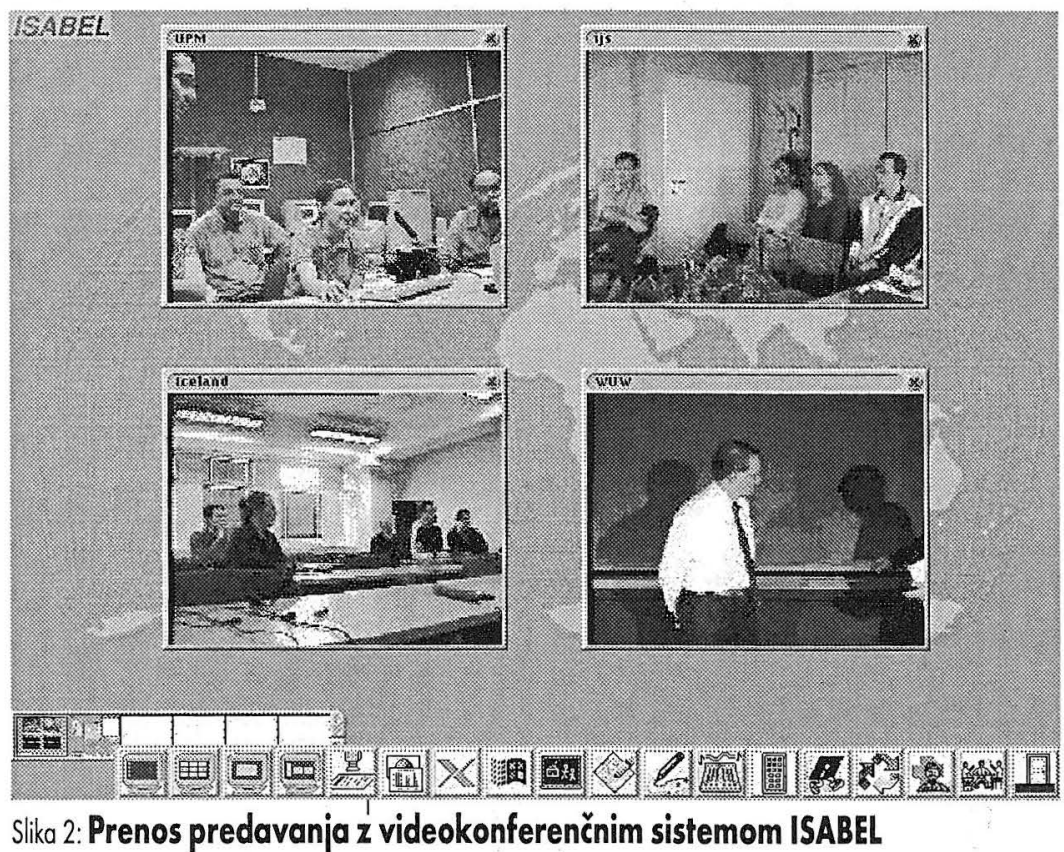
gradivo $\mathrm{z}$ iskanjem ali brskanjem po katalogu.

\section{Naročilo oziroma prijava in prenos}

V začetni fazi sistem UNIVERSAL podpira samo poslovni model, pri čemer ponudnik

Sistem UNIVERSAL podpira poslovni model izmenjave učnega gradiva. učnega gradiva najprej objavi ponudbo, uporabnik pa jo nato sprejme s prijavo oziroma naročilom učnega gradiva. Uporabniki morajo biti seznanjeni s pogoji uporabe, pred dostavo gradiva pa se morajo z njimi strinjati. Končni rezultat je pogodba med ponudnikom in uporabnikom. S tem so vsi pogoji za dostavo učnega gradiva izpolnjeni. Sledi lahko prenos gradiva prek sistemov za razširjanje. Za prenos učnega gradiva do končnih uporabnikov so na voljo različni sistemi za razširjanje in dostavo gradiva, na primer sistemi brez prenosa $\mathrm{v}$ realnem času, avdio-vizualni sistemi za predstavitev podatkov $\mathrm{v}$ realnem času in sistemi za video konference in računalniško podprto skupin- sko delo, ki omogočajo interaktivno obliko predavanj na daljavo (slika 2). Za vsak prenos mora obstajati poseben sistem za razširjanje, ki zagotavlja ustrezno kakovost storitve in varnost pri prenosu podatkov. Posebnosti izhajajo iz razlik v zahtevani interakciji in razlik v naravi učnega gradiva. Vsi sistemi za prenos gradiva so tesno povezani z osrednjim delom sistema UNIVERSAL, saj je le tako mogoče zagotoviti varen dostop do gradiva in spremljati čas uporabe za potrebe obračunavanja ter evalvacije gradiva.

\section{Evalvacija}

Evalvacija je iz uporabnikovega zornega kota ena izmed ključnih komponent sistema, saj omogoča vrednotenje ponujenega učnega gradiva in ocenjevanje same platforme ter njenih storitev. Pri evalvaciji učnega gradiva posreduje uporabnik sistemu oceno in mnenje o gradivu ter sami storitvi. Ocene temeljijo na elektronskih vprašalnikih, ki jih uporabniki izpolnijo po končanem prenosu učnega gradiva. Vprašalnikov je več vrst: za učitelje 
in učence. Nanašajo se na vsebino gradiva, njeno predstavitev, interaktivnost uporabnost in »prijaznost « gradiva ter sistema. Vrnjeni vprašalniki se shranijo v posebno bazo podatkov. Na zahtevo uporabnika (na primer ponudnika ali možnega naročnika) sistem obdela te podatke in jih nato prikaže $\mathrm{z}$ različnimi grafikoni.

\section{Dosegljivost sistema UNIVERSAL}

Vsak uporabnik (tudi neregistriran) lahko s spletnim brskalnikom svobodno brska ter išče po katalogu sistema UNIVERSAL 0. Druge storitve, kot so ponudba novega gradiva oziroma njegova objava $v$ katalogu, naročanje ter uporaba, so namenjene samo registriranim uporabnikom. Preden se lahko registriramo, mora naša ustanova, na primer fakulteta, kjer smo zaposleni ali študiramo, postati članica sistema. UNIVERSAL omogoča vsem visokošolskim ustanovam brezplačno članstvo in uporabo storitev do konca julija 2002. Dodatne informacije in dostop do storitev so na voljo na spletni strani z naslovom http://www. ist-universal.org

\section{SKLEPNE MISLI}

Sistem UNIVERSAL pospešuje razvoj in uveljavitev izobraževanja na daljavo v Evropi, saj premošča prepad med institucijami, ki pripravljajo učno gradivo in ga želijo ponuditi na trgu, ter drugimi ustanovami, ki gradivo iščejo, da bi ga uporabile v lastnem izobraževalnem procesu. Gradivo je v sistemu dostopno ne glede na njegovo obliko, posamezni deli sistema pa svetujejo uporabniku in mu pomagajo poiskati gradivo, ki ustreza njegovim potrebam. Sistem, ki si ga lahko predstavljamo tudi kot elektronski trg za potrebe izobraževanja na daljavo, zbira povratne informacije uporabnikov učnega gradiva o kakovosti storitve in opravljenega pouka, zagotavlja kakovost storitev, varnost vključenih subjektov (overjanje uporabnikov in učnega gradiva, zaupnost tajnih podatkov, avtorizacija ter nadzor dostopa do gradiva in zasebnost uporabnikov), možnost obračunavanja in plačevanja uporabe učnega gradiva ter drugih storitev prek javnih komunikacijskih omrežij, na primer interneta.

\section{VIRI IN LITERATURA}

B. Jerman Blažič, G. Vrabič, Na urniku so tudi predavanja $v$ živo: izobraževanje na daljavo in projekt UNIVERSAL, Delo, priloga Znanost, 30. maj 2001.

Blackboard, bringing education online, http://www. blackboard.com;

Click2learn - Making Knowledge a Tangible Asset, http://www.click2learn.com

DigitalThink - The Leader in E-learning Business Solutions, http://www.digitalthink.com

G. Vrabič, Mehanizmi izmenjave vsebin v sistemu eizobraževanja, magistrsko delo, Ljubljana, 2001.

S. Bernd, G. Vrabič, Learning resource catalogue design of the UNIVERSAL brokerage platform, Proceedings of ED-MEDIA 2001, Tampere, Finska; od 25. do 30. junija 2001, str. 1973-1978. 